\title{
The impact of e-commerce on transport
}

\author{
S. Basbas \\ Department of Transportation and Hydraulics Engineering, \\ Faculty of Rural and Surveying Engineering, School of Technology, \\ Aristotle University of Thessaloniki, Greece
}

\begin{abstract}
Within the framework of this paper the impact of e-commerce on transport is examined and discussed. This relatively new way of commercial activity affects modern way of life and also the environment and energy consumption. The paper attempts to identify the advantages and disadvantages of e-commerce in regards to freight transport and person trips. The use of Internet is also examined as a precondition for the success of e-commerce. Results have shown that there is need for further research in order to obtain more robust results about the implications of e-commerce on transport.
\end{abstract}

Keywords: e-commerce, transport, logistics, Internet.

\section{Introduction}

It is well known that the number of road motor vehicles has continuously been increasing all over the world. The car density in the EU has been doubled in the last 25 years to reach 463 cars per 1000 inhabitants in the year 2002 [1]. It must be mentioned at this point that the road motor vehicles are over 800 per thousand inhabitants in the United States [2], which means that the EU figure will be expected to further increase in the near future. It is also worthwhile to mention here that the number of passenger cars in the United States was 129.7 million in the year 1996 [3]. According to estimates by the Organization for Economic Cooperation and Development (OECD), the total number of vehicles in OECD countries is expected to grow by $32 \%$ from 1997 to 2020 [4]. All the abovementioned data lead to the conclusion that traffic and environmental associated problems will continue to grow in the forthcoming years unless certain measures will be implemented. One way to affect transport demand and reduce the number of trips made by passenger cars is the introduction of e-commerce. 
e-commerce is mainly based on the development of the Internet. According to Eurostat [1] access to the Internet increased for both EU households and enterprises in the year 2004. More specifically, the level of households' access to the Internet in the EU-25 was $42 \%$ (the population considered is from 16 to 74 years of age), while that of enterprises was higher at $89 \%$. According to the same source in some countries the level was over $95 \%$ of all enterprises (with more than nine employed people) while in all the other countries of the EU-25 for which data are available, this level was over $70 \%$.

The percentage of households with access to Internet for the period 2002-2004 is presented in Table 1 for various European countries.

Table 1: $\quad$ Households that have Internet access at home (\%).

\begin{tabular}{|l|c|c|c|}
\hline \multicolumn{1}{|c|}{ Year } & 2002 & 2003 & 2004 \\
\hline Dountry & & & 69 \\
\hline Norway & 56 & 64 & 60 \\
\hline Germany & - & 60 & 60 \\
\hline Luxembourg & 46 & 54 & 59 \\
\hline Netherlands & 40 & 45 & - \\
\hline United Kingdom & 58 & 59 & 56 \\
\hline Finland & 50 & 55 & 51 \\
\hline Austria & 44 & 37 & 45 \\
\hline Ireland & 33 & 36 & 40 \\
\hline Spain & - & 28 & 34 \\
\hline France & - & 31 & 34 \\
\hline Italy & 34 & 32 & 16 \\
\hline Portugal & - & 22 & 17 \\
\hline Greece & 12 & 16 & \\
\hline Sourc: 5,6$]$ & & & \\
\hline
\end{tabular}

Source: $[5,6]$.

According to a survey, which was carried out by VPRC on behalf of the GRNET in Greece [7], the use of Internet was 19.5\% (sample size for the year 2005: 2741 people, age $>15$ years old) in year 2005 (19.7 and 19.9 for the years 2004 and 2003 respectively). The results of the same survey show that the use of Internet for searching information about products and services was at a percentage of $17.6 \%$ (year 2005). When it comes to e-shopping the percentage of people who answered "yes" was 20\% (products and services include CD, DVD, video-tapes, consumables for computers, software, video games at a percentage of $51 \%$ of the total products and services refer to e-shopping). It is also very interesting to notice that a percentage of $44.6 \%$ stated that they had previously visited the respective shops before they finally proceeded with e-shopping. That practically means that nearly half of the people who actually did their shopping through the Internet also made a trip to the shop just to be informed about the product. 
According to the results of a recent survey among the 500 largest enterprises in Greece concerning the use of e-commerce, $82.2 \%$ of the enterprises had a website in year 2004 (the respective figure for the year 2003 is 80.6\%) [8].

The results of a survey carried out by the National Statistical Service of Greece concerning the reasons for which people do not have access to the Internet from their homes [6,9] are presented in Table 2.

Table 2: $\quad$ Main reasons for not having Internet access from home (adults).

\begin{tabular}{|c|c|c|c|}
\hline $\begin{array}{c}\text { Year } \\
\text { Reasons }\end{array}$ & 2002 & 2003 & 2004 \\
\hline Available connection elsewhere & $7.70 \%$ & $5.39 \%$ & $9.70 \%$ \\
\hline High cost of the equipment & $21.60 \%$ & $28.81 \%$ & $45.50 \%$ \\
\hline High cost of the Internet connection & $17.60 \%$ & $26.32 \%$ & $36.55 \%$ \\
\hline $\begin{array}{c}\text { Lack of confidence about how to use } \\
\text { the Internet }\end{array}$ & $7.40 \%$ & $16.46 \%$ & $26.31 \%$ \\
\hline Security of personal data & $1.30 \%$ & $11.01 \%$ & $20.09 \%$ \\
\hline
\end{tabular}

Source: $[6,9]$.

\section{The evolution of e-commerce}

The rapid evolution of the Internet led to the rapid evolution of e-commerce. e-commerce between enterprises started in the decade of 1970s with the introduction of the Electronic Funds Transfer (EFT) [10].

There are a lot of definitions about electronic commerce (e-commerce). e-commerce can be defined as "any method of using electronic communications and computer technology to conduct business" [11]. According to Bergendahl [12] "Electronic Commerce is an activity that makes use of a computer network (the Internet) in order (a) to exchange information about products and services including price offers, and (b) to buy and sell products, services, and information online".

e-commerce includes Business to Customer (B2C) commerce, Business to Business (B2B) commerce and Business to Government (B2G) commerce [13], with the latest to be in the early stage of development yet. Due to the extensive use of the Internet, e-commerce is also referred as Internet Commerce or i-Commerce [14].

The spread of e-commerce all over the world is a reality nowadays. For example the enterprise Amazon in Christmas 2005 managed to sell 2.8 million items in 24 hours (that means 32 sales per second) [15]. During the weeks before Christmas 2005 in the United Kingdom the consumers spent more than $£ 400$ million for shopping through the Internet (this amount was higher by $17.5 \%$ compared to what happened during the first three weeks of December 2003 [15].

According to Eurostat yearbook 2005 [1] the percentage of individuals having ordered/bought goods or services for private use over the Internet in the last three 
months exceeded 20\% in EU-15 (for men) and 15\% (for women). The respective figures in EU-25 are $15 \%$ and $10 \%$. Countries with high figures include Denmark, Germany, Luxembourg, Finland, Sweden, United Kingdom, Iceland and Norway. According to the same source, countries with high percentage of enterprises having received orders online in 2004 include Belgium, Denmark, Germany, Ireland, Netherlands, Austria, Slovenia, Finland, Sweden, United Kingdom and Norway. The EU-25 percentage for small enterprises (10-49 employees) exceeded 10\%, for medium-sized enterprises (50-249 employees) exceeded $15 \%$ and for large enterprises (250 or more employees) exceeded 25\%. The respective figures for EU-15 are 10\%, 20\% and $30 \%$.

According to the results of the survey in Greece including the largest 500 enterprises [8], a percentage of $20.8 \%$ of the enterprises made on-line sales (the respective figure for the year 2003 was $18.8 \%$ ). The results of the same survey showed that a percentage of $47.1 \%$ of the enterprises order their supplies on-line (the respective figure for the year 2003 was 47.4\%).

The success of e-commerce depends on a number of factors [16] as follows:

- Internal driver: cost leadership, reputation, market, business entry

- Internal impediment: finance, risks, expertise

- External driver: product pricing, time spent, convenience, external relationship

- External impediment: customer expense, delivery time, transaction risks, access

Profitability of e-commerce depends on the type of the transactions. Bergendahl [12] has pointed out that "the main profitability of eCommerce is supposed to come from transactions business-to-business (B2B). In the case of business-to-consumer (B2C) only a limited number of cases seem to have become a success".

Among the parameters affecting the successful deployment of e-markets is the transport infrastructure. For example, in China [17] "the current transportation networks are inefficient, the railway transportation system is overloaded, expressway construction sluggish, and postal system is too slow with delivery". This is considered as infrastructure handicap and indicates the important role transport plays in the development of e-commerce.

\section{Impact of e-commerce on transport}

The impact of e-commerce on transport can be classified as follows [11]:

- Impacts on parties in the supply chain

- Impacts on transport demand

- Impact on distribution 
The urban environment is affected by e-commerce. Bollo and Stumm [18] conclude that "the use of electronic communication will have a direct effect on logistics, by production according to demand instead of the storage of large quantities of products in warehouses and depots, and an indirect effect by modifying commercial urbanisation and distribution networks in towns".

The use of the Internet for transport related applications include timetable information, traffic information and booking transport related services. All these applications have an impact on the number of person trips daily made and the transport mode to be used. According to the project BISER [19] the highest demand levels for general use of Internet based transport services are widely found in the northern regions of Europe (Germany, UK, Sweden, Denmark, with central Finland and Paris, France of notable rank). The low demand areas are to be found in the southern regions of Europe (Spain, Portugal, Italy, southern France and Greece).

Mobile phones are also used in traffic-related services. Ramirez [20] proposes an innovative e-business platform that has been developed by a transcross European consortium within the framework of the IST Information Society Technologies of the $5^{\text {th }}$ FP. This technology combines WAP, WEB and Bluetooth and has made services accessible from the mobile phone.

It is obvious that the trip purpose, which is mostly affected by the introduction of e-commerce, is "shopping". It was estimated in the United States that one out of five person trips was made for shopping in the year 1995 [21]. In Athens (population 4,137,900 for the year 1996) according to the study on the development of the metro [22] a number of 6.8 million person trips were made (year 1996) by all transport modes. In the central municipalities of the study area the percentage of trips made by private car was $29.7 \%$. The study results showed that "shopping" was the trip purpose for the $7.5 \%$ of these trips. Therefore it can be said that a number of 151,470 trips was made by passenger cars and "shopping" was their trip purpose.

The respective figures for Thessaloniki (which is the second biggest city in the country with a population in the area of one million inhabitants) which are based on the results of the General Transportation Study [23] are as follows: 1.6 million person trips were daily made in the year 1999 of which $40.6 \%$ were made by passenger cars (either as a driver or as a passenger). The study results also showed that "shopping" was the trip purpose for the 3.6\% of these trips. Therefore the number of trips having "shopping" as a purpose was 23,386 .

It must be mentioned at this point that it is not easy to estimate the percentage of these specific trips in Athens and Thessaloniki, which could be affected (and how they can be affected) by a wide introduction of e-commerce. This happens because there is need for extensive research and data collection concerning enterprises and consumers. In addition it must be taken into account that:

- people may use their free time in order to make other types of trips (instead of trips for "shopping")

- quite often a trip for shopping is part of a wider activity which may include "return home" or "personal business" etc. 
The improvement of traffic conditions has a positive effect on the quality of the environment. Ferreira et al. in their research about the assessment of the transport impacts of e-business in Australia [24] summarize the environmental disadvantages/energy costs and environmental advantages/energy savings as follows (Table 3):

Table 3: $\quad$ Environmental impacts of e-commerce.

\begin{tabular}{|c|c|}
\hline $\begin{array}{l}\text { Environmental disadvantages/Energy } \\
\text { costs }\end{array}$ & $\begin{array}{c}\text { Environmental advantages/ Energy } \\
\text { savings }\end{array}$ \\
\hline $\begin{array}{l}\text { Increase in travel by Light Commercial } \\
\text { Vehicles (LCV) for local centre/home } \\
\text { delivery leads to high impact on } \\
\text { Greenhouse Gases (GHG) and air } \\
\text { quality. }\end{array}$ & More accessible depots. \\
\hline $\begin{array}{l}\text { More trips lead to increased energy } \\
\text { consumption and GHG. }\end{array}$ & More efficient logistic routes. \\
\hline $\begin{array}{l}\text { More Freight VKT. Rail freight } \\
\text { services will be disadvantaged. }\end{array}$ & $\begin{array}{l}\text { Less traffic delays, accidents, } \\
\text { vehicle operating costs and } \\
\text { emissions. }\end{array}$ \\
\hline
\end{tabular}

Source: [24].

e-commerce may also contribute to the provision of a sustainable transport system. Gould and Golob [25] have pointed out that "the development of localized e-commerce could provide more opportunity for sustainable transport. Commuters could become less car-dependent if personal vehicles were not needed to make multiple after-work stops, and carry goods home. These commuters might also find that they might be able to use public transport or carpools more readily".

Bussiere and Lewis in their research for Montreal and Quebec [26] have stated that "on the long term it can be expected that the combination of autonomous workers, flexible hours and telecommuting could induce a reduction in the range of $6 \%$ of morning peak travel trips, which is significant in the context of scarce resources for new infrastructures".

Finally, another important dimension of the e-commerce and more especially of the $\mathrm{B} 2 \mathrm{C}$ is the need to have a very productive system. A major part of the delivery system is the dynamic vehicle routing (DVR) system. Du et al. [27] in their research about DVR for on-line B2C delivery have strongly encouraged the use of the First-Fit-Nearest or the Best-Fit-Nearest algorithm for initial-route formation.

\section{Discussion}

e-commerce is a rather complicated issue as far as its impacts on transport are concerned. Corey [28] has pointed out "in the future, it is expected that e-commerce will expand well beyond current levels and into all other sectors of 
the global economy such as manufacturing and wholesaling and the production supply side".

Hesse [29] has mentioned that "there is some evidence that e-commerce is likely to reinforce longstanding trends of transport growth, rather than breaking them". Hesse has also point out that "future research should be directed towards the various implications of logistics technologies, organization and infrastructure".

The advantages of e-commerce for the enterprises include, among other things, the increase of the productivity, the reduced expenses on advertisement and the reduced operational cost. Advantages for the end user include fewer trips, time and money savings, direct access to services and products on a 24 hour basis, on-time delivery of products etc. The disadvantages of e-commerce for the enterprises include the complexity of the system management, the appearance of technical problems concerning the Internet etc. Disadvantages for the end user include difficulties when trying to have access to the Internet, problems with reliability and security of data provided through the Internet and not direct view about the product.

The impact of e-commerce on energy consumption in the transport sector is not so clear. On one hand the development of e-commerce can lead to the increase of energy consumption due to the increased use of trucks etc. and distance travelled (since consumers can be anywhere). On the other hand the transactions through the Internet can lead to person trip reduction for shopping, and thus to energy savings due to reduced use of private cars (in the case where the consumer uses Public Transport, the environmental benefits are questionable as far as e-commerce is concerned). The development of e-commerce will also have an impact to the land use system since smaller warehouses will replace larger ones. Land use for storing will be replaced by land use for vehicle stops and transshipment.

Since e-commerce also depends on the extensive use of Heavy Goods Vehicles and also on airplanes as well (operating during day and night) there might be an external cost of the transport sector due to the environmental impacts (e.g., noise pollution, emissions etc.).

There is also need for the provision of a suitable policy framework for e-commerce by the governments in order to secure fair-trading for all the actors involved.

It is clear that further research is needed in order to obtain more robust results about the impact of e-commerce on transport and the environment.

\section{References}

[1] Eurostat, Europe in figures, Eurostat yearbook 2005, Chapter 5, Office for the Official Publications of the European Communities, Luxembourg, 2005.

[2] OECD, Factbook 2005, Economic, Environmental and Social Statistics, Quality of life, 2005. 
[3] United States of America, Department of Transportation, Bureau of Transportation Statistics, http://www.bts.gov

[4] Kanari N., Pineau J.-L. \& Shallari S., End-of-Life Vehicle Recycling in the European Union, JOM, August 2003.

[5] Eurostat, http://epp.eurostat.cec.eu.int

[6] Newspaper Kathimerini, Sunday 5 June 2005, Greece.

[7] VPRC, National survey for the new technologies and Information Society - the use of computers in Greece, Survey assigned by the GRNET, General Secretariat of Research \& Technology, Greek Ministry of Development, 2005, e-Business Forum, http://www.ebusinessforum.gr

[8] Athens University of Economics and Business, Athens Laboratory of Research in Marketing (A.LA.R.M.), Hitech (subcontr. Datapower), HellasNet, Study for the use of e-commerce in the largest Greek enterprises through repeatable interviews with high level staff working in informatics, General Secretariat of Research \& Technology, Greek Ministry of Development, 2005, e-Business Forum, www.ebusinessforum.gr/stats

[9] Hellenic Republic, Ministry of Economy and Finance, General Secretariat of National Statistical Service of Greece, http://www.statistics.gr

[10] Bakogiannis N., Up-to-date evolution of e-commerce and trends in Greece - Case studies and study of the various forms of e-commerce in an enterprise, Postgraduate Thesis, Technical University of Crete, Department of Production Engineering \& Management, Chania 2003.

[11] Nezu, R., OECD DSTI, The impact of E-commerce on Transport, June 2001.

[12] Bergendahl, G., Models for investment in electronic commerce-financial perspectives with empirical evidence, Omega, The International Journal of Management Science, 33, pp. 363-376, 2005.

[13] Maimanakos, K., E-commerce and SME in Greece, Thesis, Technical University of Crete, Department of Production Engineering \& Management, Chania.

[14] Rigas, K.A., Digital Economy and Transport, Proc. of the $13^{\text {th }}$ Conf. of Hellenic Operational Research Society, University of Piraeus, Piraeus, pp. 549-554, 2000.

[15] Newspaper Macedonia, Sunday 1-2 January 2005, page 43, Greece.

[16] Quaddus, M. \& Achjari, D., A model for electronic commerce success, Telecommunications Policy, 29, pp. 127-152, 2005.

[17] Khalifa, M., Banerjee, P. \& Ma, L., Strategies for Successfully Deploying e-Markets: Lessons from the China Context, Proc. of the $36^{\text {th }}$ Hawaii Int. Conf. on System Sciences (HICSS '03), IEEE, Computer Society, 2002.

[18] Bollo, D. \& Stumm, M., Possible Changes in Logistic Chain Relationships Due to Internet Developments, Int.Trans.Opl.Res. Vol.5, No.6, pp. 427-445, 1998, (C) 1998 IFORS. Published by Elsevier Science Ltd.

[19] BISER, Benchmarking the Information Society: e-Europe Indicators for European Regions, BISER Domain Report No.2: Transport in the 
Information Society - The Regional Dimension, Project funded by the European Community under the "Information Society Technology" Programme, 1998-2002.

[20] Ramirez, C., e-PARKING: an e-business platform for more efficient use of parking space resources. Proc. of the $10^{\text {th }}$ Int. Conf. on Urban Transport and the Environment in the $21^{\text {st }}$ Century, eds. C.A.Brebbia \& L.C.Wadhwa, WIT Press, Dresden, pp.465-476, 2004.

[21] Spathopoulos, K., Gavanas, N. \& Tzagaroulakis, M., E-commerce an its impact on trips, research report, M.Sc. course on Design, Organisation and Management of Transport Systems, Aristotle University of Thessaloniki, 2005.

[22] Attiko Metro S.A., Study for the Development of the Metro, Report 2: Existing situation of the transport system in the prefecture of Attica, January 2000.

[23] Denco, Trademco, Aggelidis, Truth, Infodim, WS-Atkins, SDG, General Transportation and Traffic Study for the Thessaloniki Metropolitan Area, Thessaloniki, 1998.

[24] Ferreira, L., Smith, N. \& Mead, E., Assessing the transport impacts of ebusiness in Australia. Proc. of the $7^{\text {th }}$ Int. Conf. on Urban Transport and the Environment in the $21^{\text {st }}$ Century, eds. L.J.Sucharov \& C.A.Brebbia, WIT Press, Lemnos, pp. 233-243, 2001.

[25] Gould, J. \& Golob, T.F., Consumer E-Commerce, Virtual Accessibility and Sustainable Transport, Proc. of the Conf. on Social Change and Sustainable Transport, Published in: W.R.Black \& P.Nijkamp (Eds), Social Change and Sustainable Transport, Indiana University Press, Bloomington, IN, 2000.

[26] Bussière, Y. \& Lewis, P., Impact of telework and flexitime on reducing future urban travel demand: the case of Montreal and Quebec (Canada), 1996-2016. Proc. of the $8^{\text {th }}$ Int. Conf. on Urban Transport and the Environment in the $21^{\text {st }}$ Century, eds. L.J.Sucharov, C.A.Brebbia \& F.Benitez, WIT Press, Seville, pp. 279-288, 2002.

[27] Du, T.C., Li, E.Y. \& Chou, D., Dynamic vehicle routing for online B2C delivery, Omega, The International Journal of Management Science, 33, p.p. 33-45, 2005.

[28] Corey, K.E., A primer of electronic commerce and digital opportunity for local, urban and regional development planning, Monograph prepared for the Michigan Partnership for Economic Development Assistance Project of the Community and Economic Development Program of Michigan State University, 2001.

[29] Hesse, M., Shipping news: the implications of electronic commerce for logistics and freight transport, Resources, Conservation and Recycling, Elsevier Science B.V., 36, pp. 211-240, 2002. 